\title{
Hematobiochemical changes of lead Poisoning and amelioration with Coconut (Cocos nucifera L.) Water in wistar albino rats
}

\section{${ }^{*}$ [ENAGBONMA BEN JESUORSEMWEN; IYORAH IMEDA EBIKERE ${ }^{2}$; IGIEHON NICHOLAS OZEDE ${ }^{3}$ AIMUANMWOSA FRANK EGHOMWANRE}

\author{
1\&2 Department of Environmental Management and Toxicology, Faculty of Life Sciences, University of Benin, P.M.B 1154, Benin City, \\ Nigeria. \\ 3,4 Department of Microbiology, Faculty of Life Sciences, University of Benin, P.M.B 1154, Benin City, Nigeria. \\ *Corresponding Author email: benjamin.enagbonma@uniben.edu \\ Tel: +2348036482589
}

\begin{abstract}
To determine the ameliorative effect of coconut water on haematobiochemical changes due to lead poisoning in wistar albino rats for six weeks, sixty rats were assigned to four groups. $0.10 \mathrm{~g} / \mathrm{l}$ of lead and $75 \mathrm{ml}$ coconut (cocus nucifera l.) water were given orally for six weeks. The mean values of red blood cells, mean corpuscular volume, mean corpuscular haemoglobin, mean corpuscular haemoglobin concentration, red blood cell distribution width and platelets $\left(8.10 \pm 0.63\left(\times 10^{6} \mu \mathrm{l}\right), \quad 52.7 \pm 0.87\left(\mu \mathrm{m}^{3}\right), \quad 17.9 \pm 0.56(\mathrm{pg}), \quad 34.73 \pm 0.65(\mathrm{~g} / \mathrm{dl})\right.$, $17.90 \pm 0.67(\%)$ and $670.00 \pm 42.22\left(\times 10^{3} \mu 1\right)$ respectively) reduced in lead treated rats when compared with control mean values $\left(8.41 \pm 0.90\left(\times 10^{6} \mu \mathrm{l}\right), 56.60 \pm 1.55\left(\mu \mathrm{m}^{3}\right), 19.33 \pm 0.82(\mathrm{pg})\right.$, $34.93 \pm 0.90(\mathrm{~g} / \mathrm{dl}), 18.27 \pm 0.73(\%)$ and $818.33 \pm 123.68\left(\times 10^{3} \mu \mathrm{l}\right)$ respectively $)$ and these values increased in $75 \mathrm{ml}$ coconut water only group and the group of $0.10 \mathrm{~g} / 1 \mathrm{lead}+75 \mathrm{ml}$ coconut water except mean corpuscular haemoglobin, mean corpuscular haemoglobin concentration, and red blood cell distribution width of the $75 \mathrm{ml}$ coconut water only. The mean values of white blood cells, lymphocytes, total cholesterol, triglyceride, high density lipoprotein-cholesterol, low density lipoprotein-cholesterol, low density lipoprotein-cholesterol/high density lipoproteincholesterol and total cholesterol/high density lipoprotein-cholesterol increased $\left(12.23 \pm 0.57\left(\times 10^{3} \mu \mathrm{l}\right), \quad 79.83 \pm 3.87(\%), \quad 64.66 \pm 6.01(\mathrm{mg} / \mathrm{dl}), \quad 89.00 \pm 7.94(\mathrm{mg} / \mathrm{dl})\right.$, $22.67 \pm 6.93(\mathrm{mg} / \mathrm{dl}), 21.00 \pm 4.58(\mathrm{mg} / \mathrm{dl}), 1.29 \pm 0.62$ and $3.36 \pm 0.83$ respectively $)$ in the lead group when compared with mean values of control group $\left(5.83 \pm 0.74\left(\times 10^{3} \mu 1\right), 69.07 \pm 10.57(\%)\right.$, $54.00 \pm 4.04(\mathrm{mg} / \mathrm{dl}), 97.33 \pm 11.34(\mathrm{mg} / \mathrm{dl}), 20.00 \pm 3.06(\mathrm{mg} / \mathrm{dl}), 17.00 \pm 6.51(\mathrm{mg} / \mathrm{dl}), 0.97 \pm 0.41$ and $2.87 \pm 0.55$ respectively) but the mean values decreased when compared with the mean values of group of $75 \mathrm{ml}$ coconut water only and group of $0.10 \mathrm{~g} / \mathrm{l}$ lead $+75 \mathrm{ml}$ coconut water, except the mean values of high density lipoprotein-cholesterol. These results indicate that coconut water could ameliorate effects of lead toxicity @ JASEM
\end{abstract}

http://dx.doi.org/10.4314/jasem.v20i1.11

Keywords: Albino rats, Amelioration, Cocus nucifera L, Haematobiochemical, Lead toxicity.

\section{Introduction}

Contamination of the environment by heavy metals among these metals is lead has increased drastically along with the rapid development of modern industry, of which its levels have increased substantially during the last few years (Bilandz ic et al. 2009). Low levels Exposure of lead has been linked with functional and structural impairments in both human and experimental animals (Reza et al. 2008). The hematopoietic, nervous and renal tissues are the main targets of lead. Moreover, it hinders the efficiency of the hepatic, reproductive and immune function (Teijón et al. 2006 and Durgut et al. 2008). Calcium Disodium EDTA is a long-established artificial lead expellant but it is lethal to the liver and kidneys. Recently, there have been many studies on the use of natural products such as vitamins and herbal drugs to expel lead (Xu et al. 2005). There has been an increase of interest in the therapeutic potential of medicinal plants as antioxidants in reducing free radical- induced tissue damage (Siddique et al. 2000 and Koleva et al. 2002). Numerous plant products have antioxidant activity as they scavenger free radicals and inhibit of lipid peroxidation (Scartezzini and Speroni 2000 and Tapiero et al. 2002 ).

Coconut water is one of the most all-around natural product with increasing scientific evidence that support the position of coconut water in health and medicinal application (Ajibogun and Oboma 2013). Anurag and Rajamohan (2003), in his work on 
Cardioprotective effect of tender coconut water in experimental myocardial infarction reported that Coconut water may offer protection against myocardial infarction. Interestingly, a study done by Alleyne et al (2005) has shown that regular consumption of either coconut water or mauby (a liquid extracted from the bark of the mauby tree, Colubrina arborescens), or particularly, a mixture of them, is effective in bringing about the control of hypertension. It is thought that coconut water could be used as important option for oral rehydration and even so for intravenous hydration of patients in remote region due to its electrolyte content (Pumer et al. 2001). Some of the important components in coconut water are cytokinins, which are class of cytochromes (Miller et al. 1955). These cytokinins showed anti-ageing, anti-carcinogenic and antithrombotic effects. (Rattan and Clark (1994); Sheu et al. (2004)). Anti-platelet properties and may be potential therapeutic agent for treating arterial thrombosis. Kinetin inhibits platelet aggregation in human platelets when stimulated by an agonist (Barciszewski et al. 2007) and could therefore help to prevent blood clots (Heo et al. 2002). Coconut water also contains folate also known vitamin B9. It was identified in the late 1930s as the nutrient required in reducing anemia in pregnancy which also help to prevent mitochondrial toxicity induced by methanol metabolites (Jackson et al. 2004). Antioxidant actions of polyphenolics derived from plants have claimed beneficial health functions for reducing cardiovascular diseases (Scalbert et al. 2005). Moreover, the presence of ascorbic acid in the natural Coconut Water was correlated with antioxidant properties (Mantena et al. 2003). João et al in their work on Evaluation of Chemical Constituents and Antioxidant Activity of Coconut Water (Cocus nucifera L.) and Caffeic Acid in Cell Culture highlighted the importance of coconut water as a nutritious food and its antioxidant properties. All varieties showed good antioxidant potential, highlighting the green dwarf which showed the best results in scavenging DPPH radical and in protecting lipids against the formation of TBARS, as well as recording the highest levels of total phenols and vitamin C. they also observed that the industrialized processes, such as UHT and lyophilization drastically reduced the coconut water contents and, therefore, its therapeutic properties. Moreover, in cell culture the green dwarf water was effective in protecting fibroblasts against damage induced by hydrogen peroxide. Finally, the chromatographic analysis confirmed the presence of the caffeic acid, which proved to be effective in inhibiting the in vitro TBARS formation.

\section{MATERIALS AND METHODS}

Procurement of experimental animals, lead sulphate and coconut (Cocos nucifera L.) water: Wistar albino rats of approximately body weight of $140 \pm 5 \mathrm{~g}$ were purchased from the breeding unit of the Department of Animal and Environmental Biology, Faculty of Life Sciences, University of Benin, Benin City. They were kept in wooden cages ( 45 by 30 by $20 \mathrm{~cm}$ ) with wire mesh covers on the cages and were fed regularly with rat pellet obtained from Ewu, Edo State, Nigeria and water ad libitum for a period of 2 weeks for proper acclimatization. Lead Sulphate $\left(\mathrm{PbSO}_{3}\right)$ with a laboratory reagent grade was procured from Paten Chemicals in Benin, Nigeria. Coconut (Cocos nucifera L.) Water obtained from traditional coconut harvested from a non industrialized area in Benin City.

Experimental design: Total of 60 healthy rats were randomly assigned to the control and treatment groups. Four groups of rats consisting of 5 rats in each group were used for the study. $0.1 \mathrm{~g} / \mathrm{l}$ lead sulphate and $75 \mathrm{ml}$ coconut water were orally administered daily by using distilled water as means of transportation for 6weeks. The groups and the doses used for this study are shown below:

Group 1: dose of lead at $0.10 \mathrm{~g} / \mathrm{l}$ of water, Group 2: $75 \mathrm{ml}$ Coconut (Cocus nucifera L.) water, Group 3: Dose of lead at $0.10 \mathrm{~g} / \mathrm{l}$ of water $+75 \mathrm{ml}$ Coconut (Cocus nucifera L.) water, Group 4: the healthy control group.

Four rats from each group were randomly sacrificed at every fortnight intervals after starting the experiment i.e. 2,4 , and 6 weeks.

Collection of samples for haematology: Blood samples were collected from the heart of dissected albino rats using $5 \mathrm{ml}$ disposable sterile syringes and were transferred into tubes containing potassium EDTA anticoagulant for complete blood count (CBC) analysis. The sample bottles were then kept in ice briefly and were transferred to the Haematological laboratory unit of UBTH, where they were analyzed.

Haematological parameter analysis: The following blood parameter were analyzed; white blood cells (WBC), red blood cells (RBC), blood platelets count, haemoglobin content, hematocrit percent ( $\mathrm{HCt} \%)$, mean corpuscular volume (MCV), mean corpuscular haemoglobin $(\mathrm{MCH})$, mean corpuscular haemoglobin concentration (MCHC), lymphocytes, red blood cell distribution width (RDW), were obtained from CBC analysis by a full-automated Sysmex Hematology Instrument and Sysmex Cell counter (Sysmex, Japan) using the methods of Dacie and Lewis 1991).

\section{${ }^{*}$ ENAGBONMA BEN JESUORSEMWEN; IYORAH IMEDA EBIKERE ${ }^{2}$; IGIEHON NICHOLAS OZEDE 3} AIMUANMWOSA FRANK EGHOMWANRE 
Lipid profile collection: Blood collected from rats in each group were directly transferred into the sterile test tube and allowed to clot. The serum was collected and stored at $4^{\circ} \mathrm{C}$ in a refrigerator until it was used for Biochemical analysis.

Lipid profile analysis: Total cholesterol, Triglyceride, High Density lipoprotein-cholesterol (HDL-ch), Low Density lipoprotein-cholesterol (LDL-ch), Low Density lipoprotein-cholesterol/High Density lipoprotein-cholesterol (LDL/HDL), Total cholesterol/High Density lipoprotein-cholesterol (TL/ HDL) were determined by a full-automated Sysmex Hematology Instrument.

Statistical analysis: Data collected from the study were analyzed using general descriptive statistics, one Way Analysis of Variance (ANOVA) at 95\% probability level of significant. If significant differences were found, Duncan's multiple range tests was used to compare the different experimental groups. Computer software Statistical Package for Social Scientists (SPSS) and Microsoft Excel were used for the statistical analyses.

\section{RESULTS AND DISCUSSION}

The results (Table 1) of this study revealed that there were no significant differences $(\mathrm{P}>0.05)$ between the mean values of RBC, MCV, MCH, MCHC, RDW and PLT when compared with the mean values of the control group, however, there were reduction in the mean values of RBC, MCV, MCH, MCHC, RDW and PLT when compared with the control group.

Table-1: Haematological parameters (mean and SE) in animals of different experimental groups

\begin{tabular}{|c|c|c|c|c|}
\hline Parameter & $\begin{array}{l}\text { Lead at } 0.10 \mathrm{~g} / \mathrm{l} \\
\text { of water }\end{array}$ & $\begin{array}{l}\text { 75ml Coconut } \\
\text { Water }\end{array}$ & $\begin{array}{l}\text { Lead at } 0.10 \mathrm{~g} / \mathrm{l} \text { of water } \\
+75 \mathrm{ml} \text { Coconut. Water }\end{array}$ & $\begin{array}{l}\text { healthy control } \\
\text { group }\end{array}$ \\
\hline $\mathrm{WCB}\left(\times 10^{3} \mu \mathrm{l}\right)$ & $12.23 \pm 0.57$ & $9.50 \pm 1.54$ & $10.97 \pm 2.11$ & $5.83 \pm 0.74$ \\
\hline LYM (\%) & $79.83 \pm 3.87$ & $62.6 \pm 11.83$ & $76.3 \pm 4.94$ & $69.07 \pm 10.57$ \\
\hline $\mathrm{RBC}\left(\times 10^{6} \mu \mathrm{l}\right)$ & $8.10 \pm 0.63$ & $9.78 \pm 0.39$ & $8.12 \pm 0.53$ & $8.41 \pm 0.90$ \\
\hline HGB (g/dl) & $15.6 \pm 0.35$ & $16.67 \pm 0.62$ & $15.7 \pm 1.65$ & $16.13 \pm 0.57$ \\
\hline HCT $(\%)$ & $40.17 \pm 5.99$ & $50.50 \pm 0.60$ & $41.73 \pm 0.99$ & $40.70 \pm 2.25$ \\
\hline $\operatorname{MCV}\left(\mu \mathrm{m}^{3}\right)$ & $52.7 \pm 0.87$ & $51.73 \pm 1.67$ & $53.07 \pm 0.41$ & $56.60 \pm 1.55$ \\
\hline MCH (pg) & $17.9 \pm 0.56$ & $17.3 \pm 0.21$ & $17.93 \pm 0.19$ & $19.33 \pm 0.82$ \\
\hline $\operatorname{MCHC}(\mathrm{g} / \mathrm{dl})$ & $34.73 \pm 0.65$ & $34.1 \pm 0.71$ & $34.53 \pm 0.86$ & $34.93 \pm 0.90$ \\
\hline RDW (\%) & $17.90 \pm 0.67$ & $17.67 \pm 0.18$ & $18.23 \pm 0.38$ & $18.27 \pm 0.73$ \\
\hline PLT $\left(\times 10^{3} \mu \mathrm{l}\right)$ & $670.00 \pm 42.22$ & $796.67 \pm 77.05$ & $698.33 \pm 120.22$ & $818.33 \pm 123.68$ \\
\hline
\end{tabular}

The reduction in the mean values of $\mathrm{RBC}, \mathrm{MCV}$, $\mathrm{MCH}, \mathrm{MCHC}$ and RDW might be due to decreased life span of erythrocytes ( Julian 1971) and increased fragility of erythrocytes (Donavick 1966) and inhibitory effect of lead on erythrocyte enzymes(GA3PD \& G6PD) ( Stone and Soares 1976). Similar observations were made by MuGahi et al. (2003) in adult rats. When these mean values $\mathrm{RBC}, \mathrm{MCV}, \mathrm{MCH}, \mathrm{MCHC}, \mathrm{RDW}$ and PLT of the lead group were compared with the $75 \mathrm{ml}$ Coconut (Cocus nucifera L.) water only group and the group of lead at $0.10 \mathrm{~g} / 1$ of water+ $75 \mathrm{ml}$ Coconut (Cocus nucifera L.), although there were no significant differences $(\mathrm{P}>0.05)$ but the values were higher than those of the lead group except in $\mathrm{MCH}, \mathrm{MCHC}$, RDW of the $75 \mathrm{ml}$ Coconut (Cocus nucifera L.) water only. All mean values of RBC, MCV, MCH, RDW and PLT in the group of Lead at $0.10 \mathrm{~g} / \mathrm{l}$ of water+ $75 \mathrm{ml}$ Coconut (Cocus nucifera L.) were higher than the mean values of lead group except the mean values of MCHC. The ability of the coconut water to counteract the reduction might be due to the fact that Coconut water contains iron and folate also known vitamin B9. It was identified in the late 1930s as the nutrient required in reducing anemia in pregnancy which also help to prevent mitochondrial toxicity induced by methanol metabolites (Jackson et al. 2004), anti inflammatory effect, anti-thrombotic effects and antioxidant property of Coconut (Cocus nucifera L.) water (Scalbert et al. 2005; Barciszewski et al. 2007; Rattan and Clark (1994); Sheu et al. (2004). An increase in the mean values of WBC and LYM were observed in lead fed rats when compared to control, although there were no significant differences $(\mathrm{P}>0.05)$. The increased values of $\mathrm{WBC}$ and LYM might be due to lead inflammation in tissues and Lymphocytopenia might be due to pathological changes that were taken place in spleen and lymphnode (Yagminas et al. 1990 ) and This is a likely response to metal poisoning (Stock and Hoffman 2000). These mean values of WBC and LYM reduced in the $75 \mathrm{ml}$ Coconut (Cocus nucifera $L$.) water only group and the group of lead at $0.10 \mathrm{~g} / \mathrm{l}$ of water+ $75 \mathrm{ml}$ Coconut (Cocus nucifera L.) when compared with the lead group.

Lipid and lipoprotein abnormalities play a key role in the pathogenesis and progression of atherosclerosis 
and cardiovascular diseases (Chrysohoou, et.al. 2004; Glew et.al. 2002). From the result (Table 2) of this work, there were increase mean values of total cholesterol (TC) $(\mathrm{P}>0.05)$, High Density Lipoprotein (HDL-ch) $(\mathrm{P}>0.05)$, Low Density Lipoprotein (LDLch) $(\mathrm{P}>0.05)$, Low Density Lipoprotein/High Density
Lipoprotein-cholesterol (LDL/HDL-ch) $(\mathrm{P}>0.05)$ and total cholesterol/ Density Lipoprotein (TL/HDL) $(\mathrm{P}>0.05)$, and a decrease mean values in Triglyceride $(\mathrm{P}>0.05)$, were observed in lead fed rats when compared to control.

Table-2: lipid parameters (mean and SE) in animals of different experimental groups

\begin{tabular}{lllll}
\hline Parameter & $\begin{array}{l}\text { Lead at } \mathbf{0 . 1 0 g} / \mathbf{l} \\
\text { of water }\end{array}$ & $\begin{array}{l}\mathbf{7 5 m l ~ C o c o n u t} \\
\text { Water }\end{array}$ & $\begin{array}{l}\text { Lead at } \mathbf{0 . 1 0 g} / \mathbf{l} \text { of water+ } \\
\mathbf{7 5 m l} \text { Coconut Water }\end{array}$ & $\begin{array}{l}\text { healthy control } \\
\text { group }\end{array}$ \\
\hline TL (mg/dl) & $64.66 \pm 6.01$ & $63.66 \pm 10.73$ & $59.33 \pm 3.53$ & $54.00 \pm 4.04$ \\
Trig (mg/dl) & $89.00 \pm 7.94$ & $76.00 \pm 7.09$ & $83.33 \pm 26.56$ & $97.33 \pm 11.34$ \\
HDLC (mg/dl) & $22.67 \pm 6.93$ & $29.33 \pm 10.40$ & $24.33 \pm 4.19$ & $20.00 \pm 3.06$ \\
LDLC (mg/d) & $21.00 \pm 4.58$ & $19.33 \pm 1.86$ & $18.33 \pm 6.94$ & $17.00 \pm 6.51$ \\
LDL/HDL & $1.29 \pm 0.62$ & $0.86 \pm 0.31$ & $0.84 \pm 0.42$ & $0.97 \pm 0.41$ \\
& & & & \\
TL/HDL & $3.36 \pm 0.83$ & $2.46 \pm 0.43$ & $2.58 \pm 0.37$ & $2.87 \pm 0.55$ \\
\hline
\end{tabular}

The findings of Shyam, et.al. 2012, indicated that exposure to lead alters the metabolism of cholesterol and thus increases the risk of cardiovascular disease and atherosclerosis in lead-exposed subjects, with an increase in total cholesterol (TL), Low Density Lipoprotein (LDL-ch) and Low Density Lipoprotein/High Density Lipoprotein-cholesterol (LDL/HDL-ch) and decrease in High Density Lipoprotein (HDL-ch). Although, the results (Table 2) of this study, there was increase in the values of high Density Lipoprotein (HDL-ch) in Coconut (Cocus nucifera L. ) water ameliorated groups when compared with the values of lead fed groups, however, there were reductions in the values of total cholesterol (TL), LDL-ch, LDL-ch/HDL-ch, (TL/HDL) and triglycerides. Sandhya and Rajamohan in their work to determine the effect of coconut water feeding in cholesterol fed-rats reported that both tender and mature coconut water were capable of counteracting the increase in total cholesterol, VLDL, LDL cholesterol and triglycerides while high density lipoprotein cholesterol was higher caused by the cholesterol feeding. The knowledge of the cholesterol subfractions is more meaningful than simple plasma total cholesterol level. The higher the Low Density Lipoprotien-cholesterol (LDL-ch), the greater the athreosclerosis risk and conversely the higher the HDL-ch, the lower the risk. This is true for humans from different racial and ethnic back grounds and observed at all adult ages (Baron 2000). In this work, the TL/HDL and LDL/HDL values were smaller than the control values; this may be because of the anti-oxidant and anti-inflammatory effects of Coconut (Cocus nucifera L.) water. Oram and Lawn (2001) reported that anti-oxidant and antiinflammatory effects may obviate processes that initiate atherogenesis.
Acknowledgment : I wish to express my heartfelt gratitude to my project supervisor Prof. (Mrs) P. Tawari-Fufeyin. I also acknowledge Miss Iyorah Imeda Ebikere and Mr. Igiehon Nicholas Ozede for their profound assistance, understanding and constant availability throughout the period of this research.

\section{REFERENCES}

Ajibogun OA. and Oboma YI (2013). Biochemical Composition of Coconut Water: Nigeria Species. Int $\mathrm{J}$ of Med and Bio Sci 1(1):1-4

Anurag P and Rajamohan, T (2003). Cardioprotective effect of tender coconut water in experimental myocardial infarction. Plant Foods. Hum. Nutr 58(16):1-12.

Alleyne T, Roache S, Thomas C and Shirley, A.( 2005). The control of hypertension by use of coconut water and mauby: Two tropical food drinks. West Indian Med. J 54:3-8.

Barciszewski J, Massino F and Clark, BF (2007). Kinetin - a multi-active molecule. Int J. Biol. Macromo 40: 182 - 192.

Bilandz ic' N, Sedak M., Vrataric' D, Peric' T and $\mathrm{S}^{\sim}$ imic $^{\prime} \mathrm{B}$ (2009). Lead and cadmium in red deer and wild boar from different hunting grounds in Croatia. Sci. Total Environ., 407: 4243-4247.

Baron RB (2000). Lipid abnormalities. In: Tierney Jr. LM,Mephee SJ; PapadakinsMA (Eds.), Current Medical Diagnosis and Treatment. Cgraw Hill, pp.1198-1210.

Chrysohoou C, Panagiotakos DB, Pitsavos C, Kosma K, Barbetseas J, Karagiorga M, Ladi I; 
andStefanadis C (2004). Distribution of serum lipids and lipoproteins in patients with beta thalassaemia major; an epidemiological study in young adults from Greece. Lipids Health Dis , $3: 3$.

Dacie JV and Lewis SM (1999). Practical Haematology. $8^{\text {th }}$ Ed. Pp262-270. Churchill Livingstone. London.

Donawick WK (1966). Chronic lead poisoning a cow. JAVMA 148: 655-661.

Durgut R, Koc A, Gonenci R., Bal R, Celik S, Guzel M, Altug M and Atesoglu E (2008). Effects of high dose lead toxication on liver, kidneys, heart, brain and blood in rabbits: an experimental study. J Appl Biol Sci 2: 11- 18.

Glew RH, Kassam HA, Bhanji RA, Okorodudu A and VanderJagt DJ (2002). Serum lipid profiles and risk of cardiovascular disease in three different male populations in northern Nigeria. $\mathrm{J}$ Health Popul Nutr 20:166-174.

Heo HJ, Hong SC, Cho HY, Hong B, Kim HK, Kim EK and Shin, D.H(2002). Inhibitory effects of zeatin isolated from fiatoua villosa, on acetyl cholinesterase activity from PC12 cells. Mol. Cell 13: 113 - 117 .

Jackson JC, Gordon A, Wizard G, Mc-Cook K and Rolle R (2004). Changes in chemical composition of coconut (Cocos nucifera $L$ ) water during maturation of the fruit. J. Sci food Agric 54: $1049-1052$.

Julian CJ (1971). Lead poisoning. Sci Americ 224:15-24

Koleva II, Van Bleek TA, Linssen JP, De-Groot A and Evstatieva, LN (2002). Screening of plant extracts for antioxidant activity: a comparative study on three testing methods. Phytochem Anal13(1): 8- 17.

Mantena SK, Badduri SR, Siripurapu KB and Unnikrishnan MK (2003). In vitro evaluation of antioxidant properties of Cocos nucifera Linn. water. Nahrung 47: 126-131.

Miller CO, Skoog F, Von Saltza MH and Strong FM (1955). Kinetin, a cell division faction from deoxyribonucleic acid. J. Am. Chem. Soc 77: $1392-1393$.
MuGahi MN, Heidar Z, SaGheb HM and Barbarestani, M (2003). Effects of Chronic lead acetate intoxication on blood indices of male adult rat. DARU 11(4): 147-151.

Oram JF and Lawn RM (2001). The gatekeeper for eliminating excess tissue cholesterol. J lipid Res 42:1173-1179.

Pumer S, Hail P, Maleck W and Petroianu, G (2001). Influence of coconut water on hemostasis. Am. J. Emerg. Med. 19: 287 - 289.

Rattan SI and Clark BF (1994). Kinetin delays the onset of ageing characteristic in human fibroblast. Biochem - Biophys. Res. Commun. 201: $665-672$.

Reza B, Ali N, Azhdar H, Alireza A and Ali K (2008). Effects of low-level lead exposure on blood pressure and function of the rat isolated heart. Indian J Pharmacol 40(2):69-72

Sandhya VG and Rajamohan T (2006). Beneficial effects of coconut water feeding on lipid metabolism in cholesterol-fed rats. J. Med Food 9(3):400-407

Teijón C, Olmo R., Blanco D, Romer A and Teijón JM.(2006). Low doses of lead: effect on reproduction and development in rats. Biol Trace Elem Res 111: 51- 165.

Scalbert A, Johnson IT and Saltmarsh M ( 2005). Polyphenols: Antioxidants and beyond. Am J Clin Nutr 81: 215-217.

Sheu JR., Hsigo G, Shen MY, Chou CY, Lin CH, Chen TF and Chou DS (2004). Inhibitory mechanism of kinetics, a growth promoting Hormone, in platelet aggregation. Platelet 14: $189-196$.

Siddique MS, Eddeb F, Mantle D and Mendelow AD (2000). Extracts of Ginkgo biloba and Panax ginseng protect brain proteins from free radical induced oxidative damage in vitro. Acta Neurochir. Supp76: 87-90.

Scartezzini P and Speroni E ( 2000). Review on some plants of Indian traditional medicine with antioxidant activity. J Ethnophamacol 71 (1-2): 23- 43

Stock W and Hoffman R (2000). 'white blood cells, non-malignant disorders. Lancet 355:1351-7. 
Stone CL and Soares JH (1976).The effect of dietary selenium level on lead toxicity in the Japanese quail, Poultry Science 55: 341-349.

Shyam VS, Pradeep K, Virendra A, Anoop V and Murthy R ( 2012). Lipid profiles with increase blood lead level: risk of cardiovascular disease in battery workers of Lucknow City. J Indian Acad Forensic 34(4): 0971-0973.

Tapiero H, Tew KD and Ba GN (2002). Polyunsaturated fatty acids (PUFA) and eicosanoids in human health and pathologies. Biomed Pharmacother 56(2): 200- 207.
Xu Y, Li G, Han C, Sun L, Zhao R. and Cui S (2005). Protective effects of Hippophae rhamnoides $L$. juice on lead- induced neurotoxicity in mice. Biol Pharm Bull. 28(3): 490-494.

Yagminas AP, Franklin CA, Villeneuve DC, Gilman AP, Little PB and Valli VE (1990). Sub chronic oral toxicity of Triethyl lead in the male weanling Rat. Clinical Biochemical Hematological and Histopathological effects. Fundamentals of Applied Toxico 15: 580-596. 